\title{
Legacies and pitfalls amongst the African Evangelicals: A Kenyan experience from a historical perspective
}

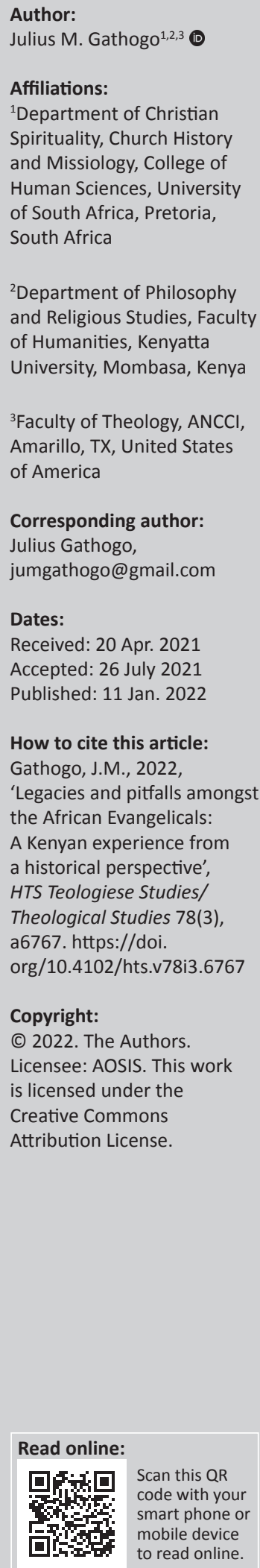

The research study sets out to explore the contribution of the African Evangelicals in both the colonial and post-colonial Kenya to the social lives of the nation. Can't it be viewed as a positive social influence or an ecclesiastical pitfall? In utilising a socio-historical design, it poses the question: how did the Evangelical European Missionaries demonstrate their theological and social influences in Kenya, and how did the post-missionary Evangelical-leaning leaderships play out? And was Muthirigu Dance an extremist reaction against the rigidity of the Evangelicals? Methodologically, this article will attempt to explore the Evangelical European Missionary Christianity, especially the Church Missionary Society that entered Central Kenya in the early 1900s, and assess the way in which they handled indigenous cultures of the local Africans. It has also attempted to critically explore their social influences in both colonial and post-colonial Kenya (1895-2021). The CMS has been given more emphasis in this article as an Evangelical society so as to help in bringing out the specific Evangelical activities in the Kirinyaga County of Kenya. Overall, the article has endeavoured to hypothesise that Eurocentrism was not the Evangelical problem, as there were diverse European missionaries, such as the High Anglican Church, the Roman Catholic and the Lutherans who were nonEvangelicals, and who were not necessarily dogmatic and rigid.

Contribution: This study adhered to the HTS journal's vision and scope by its focus on the histories of the Evangelical European Missionaries of the 19th and 20th centuries, their interactions with the local religio-cultures, and how it later played out amongst the Africans.

Keywords: legacies and pitfalls amongst African Evangelicals; Evangelical European Missionaries; Chief Njega wa Gioko; Muthirigu dance; Moi and Chiluba's leaderships.

\section{Introduction}

Evangelicalism is the brand of Christianity that emerged from the 'pietistic stream of the Reformed tradition; and its emphasis is on salvation through personal encounter with the risen Christ' (Gathogo 2017:72). Characteristically, Evangelicals emphasise on being 'born again', as in the case of Jesus' words to the Pharisee man and a member of the Jewish Council (Nicodemus) that 'no one can enter the kingdom of God unless they are born of water and the Spirit' (Jn 3:5-8). Hence, the centrality of elaborate confession, conversion and/or salvation, in all Evangelical groups, is mandatory amongst Evangelical Christianity. Certainly, Evangelicalism, even within the African context, is largely 'dominated by a western understanding of the phenomenon' (Balcomb 2016:117).

In this research article, the 'Evangelical European missionaries' refer to the Evangelical Protestant missionary societies that emerged in Kenya at the advent of colonialism in the early 19th century and the first half of the 20th century. Such missionary societies included the African Inland Mission, the Methodist Missions, the Scottish Missions (Presbyterians) and, more importantly, the Church Missionary Society (CMS), which is studied in this article. Amongst them, CMS is the precursor body for the Anglican Church in Kenya since 1844 (Gathogo 2008:68). As colonial hegemony and the missionary enterprises began to shape up in the present-day Kirinyaga County and the surrounding areas, by 1900, it found Africans with their own leaders (Athamaki, meaning the revered leaders). The Evangelical CMS was comfortable with the colonial administrative structures, as they were used to it right from their home countries. The strangeness of the African form of governance could not attract the Evangelicals who saw it as too secular and lacking religiosity.

In the 21st century, the most elaborate Evangelical Movement is the Lausanne Movement whose vision is 'taking the whole gospel to the whole world' (Gathogo 2017:73). As will be noted, Evangelicalism is not a mere Pentecostal activity; rather, it was evident even during the post-

Note: Special Collection: The World in Troubled Times: Oral History Challenges and Opportunities, sub-edited by Christina Landman (University of South Africa) and Sekgothe Mokgoatšana (University of Limpopo). 
industrial revolution Europe when an Anglican Cleric, Rev. John Wesley, was attempting to revive Christianity in UK, a phenomenon that led to the birth of the present-day Methodist Church. Nevertheless, the Lausanne Movement got a major boost in 1966, when the founder's association, Billy Graham's Evangelistic Association, partnered with America's Christianity Today magazine and sponsored the World Congress on Evangelism in Berlin (Lausanne 2021:1), which enriched this Evangelical movement greatly. Prior to the convening of the World Congress on Evangelism in Berlin 1966, the American Baptist Church leader, Evangelist Billy Graham, had already began preaching internationally, as he sought to 'Unite all Evangelicals in the common task of the total evangelization of the world'. The Berlin Conference of Evangelicals was followed by the Lausanne Conference, Switzerland, of 1974, which attracted 2,700 delegates from over 150 nations. It also included speakers who subscribe to the Evangelical faith from across the denominational divides. They included John Stott (1921-2011) who was a leading Anglican scholar, and Ralph D. Winter (1925-2009) who was a celebrated Christian thinker of his time, and whose plenary address brought in the concept of the "unreached peoples of the world'. There were others including Francis August Schaeffer (1912-1984) who was a top Presbyterian Priest and Carl Ferdinand Howard Henry (1913-2003) who was an American theologian who provided intellectual and institutional leadership (Lausanne 2021:1). Henry, a Baptist Cleric, called the Evangelicals to differentiate themselves with separatist fundamentalists. He was involved in the creation of several Evangelical organisations that included Fuller Theological Seminary, which was founded in 1947, and Evangelical Theological Society, which was established in 1949. Another major speaker during the Lausanne Conference, Switzerland, of 1974 included Samuel Escobar (1934-). Escobar was a native of Peru and a leading Latin American theologian (Gathogo 2017:72-87). In their 10 days of discussions, prayer, worship and fellowship, the participants and guests were thus able to affirm Evangelicalism as a phenomenon that goes beyond the confines of denominationalism. In any case, evangel, as a term, comes from the Greek word, which means the good news of Jesus Christ.

To this end, Anthony Balcomb explains that Evangelicalism, as a term, is intended to include both Pentecostal and Charismatic movements, as well as those who do not identify with these movements but those 'who believe in the need for personal salvation and Christian discipleship through adherence to scripture' (Balcomb 2004:146). In other words, it will also include a number of people in the so-called 'mainline' or ecumenical churches. That is, the Anglicans, the Methodists, the Lutherans, the Roman Catholics and so on (Balcomb 2004:146). As implied in the above Lausanne Conference of 1974, where leading scholars from across the denominational divides turned up as key speakers, the Evangelical Christianity and/or Evangelical theology is not just for the mainline European led Protestants or missionary churches (refer to Anglicans, Presbyterians, Reformed, Baptists and the Methodists) and / or the African-Pentecostals ${ }^{1}$ (the African Redeemed Gospel, the Gospel Outreach, the Full Gospel and the Apostolic churches). Furthermore, it is clear that Eurocentrism is not tantamount to 'the Evangelical problem', as there were other European-led missionary societies and churches, such as the High Anglican Church, the Roman Catholic and the Lutherans who were non-Evangelical and were not necessarily dogmatic and rigid in their entirety. Equally, there are both African-initiated churches that are either Evangelical or non-Evangelical across the denominational divides. Indeed, Evangelical theology is also visible amongst the Charismatic wing of the Roman Catholic Church. Similar to the above Protestant groups, and especially the Afro-Pentecostals, the Roman Catholic charismatics place more emphasis on spiritual gifts, elaborate worship, deep meditation in prayer and the power of the 'Word' amongst other visible characteristics.

\section{Church Missionary Society as an Evangelical strand}

The first CMS missionaries in Kirinyaga County of Central Kenya were Evangelical. They reached Githuguya-Sagana of the present-day Kirinyaga county in 1907 after crossing over from the neighbouring Weithaga-Murang'a Centre, where they had set up a base in 1903 (Gathogo 2001:23). They surveyed the area, in the place where we have Sagana Technical School, and planned to return and put up an Evangelical Centre for the CMS. It was only in 1908 that they met the local Muthamaki (singular for Athamaki), Njega wa Gioko. It was still in 1908 when Njega wa Gioko, Gutu wa Kibetu and other regional Athamaki were publicly installed by the colonial authorities in the then regional headquarters called Mbiri, renamed Fort Hall in 1901, and Murang'a in 1963.

Certainly, the coming of colonial administration in Central Kenya in the 1890s ushered a change of titles for leaders, as the people's leaders (Athamaki) were converted to Chiefs, and now controlled by the new team, as they made them collect poll tax and hut tax. With the loss of direct powers, Athamakiturned Chiefs found themselves in a dilemma as they had to satisfy religio-cultural needs of the locals and those of the colonial administrators. Hence, colonialism by 1908 had introduced the title of a Chief, for leaders, throughout the Central Kenya region. It is important to note that the rise of European administrators in the region prepared room for missionaries. As Assa Okoth noted, the cross always followed the flag in the British missions (Okoth 2006:31). In other words, it was the colonial authorities who first moved to a particular site, hosted the Union Jack, after which the English missionaries followed suit. This is, however, problematic as the pioneer CMS missionary in Kenya, Ludwig Krapf, arrived in the Kenyan Coast in 1844, even before the Berlin conference of 1884-1885. Krapf occupied Leven House briefly as he planned his Evangelical activities (Gathogo 2020a:1-15). In turn, Leven House, which stands adjacent to the infamous

1.Afro-Pentecostals are, indeed, a hybrid of Christian model that blend together Pentecostal and charismatic practices and African religiosity. Certainly, they capture the African ethos of wholeness, especially in the 21 st century. 
Fort Jesus, is a three-floor-storey building, was gifted to a British operative, Captain Owen in 1822, by the Mazrui dynasty, an Oman Arabic Muslim family and one of the major dynasties in Oman. By then, Captain Owen and his team were fighting slave trade along the Indian Ocean. During those days, Captain Owen was the Commander of the British Navy Ship, OHMS Leven, and hence, the reason for renaming it the Leven House. As noted earlier, the Mazrui Muslim Arabs, living in Mombasa city of Kenya, originally came from Oman. They gave out their magnificent house to the British as a measure of seeking help so as to stop an impending attack on them by a rival ruling dynasty, the Al Busaidi, who had already taken over both Zanzibar and Oman. The house was later used as a centre of British operations in East Africa, as they sought to penetrate the interior of East Africa. This included the British explorers, geologists, colonialists, and even the Evangelical English missionaries (the CMS) (Al-Amin 1995:46).

As Evangelicals, the CMS who came to the present-day Kirinyaga county, like in the rest of Africa, traced their theological standpoint from the Evangelical Movement that was started by a group of Christians at Oxford in 1735 (Gathogo 2008:43-70). These Anglican Evangelicals became the so-called the Low Anglicans, as opposed to the High Anglicans (the Anglo-Catholics). The Evangelical CMS met the newly installed Chief Gioko, in 1908, and were dissuaded from setting up a Mission Centre at Githuguya-Sagana, and were instead encouraged to settle at Njumbi-Mutira (Mutira hill). Was Chief Njega wa Gioko interfering with the missionary work, as he pushed them upstream, in the cold Hyenainfested and bushy upper hills of Mutira, as opposed to the warm and lower habitable Githuguya-Sagana area? Was this the first clash between Evangelical missionary theologies and the oral-indigenous theologies of the locals? As noted in Gathogo (2008), the Evangelical theologies of the CMS were:

$[I]$ ndividualistic, selective, biased, pietistic, unreflective and to an extent, ethnocentric. Its being ethnocentric can be seen in the fact that it did not have room for cultures outside the British territories. In addition, it embraced cultural norms that often contradicted some of the British cultural norms and values such as abstaining from drinking, dancing, sex (unless it was for procreation), smoking, possession of worldly things, secular life, and so on. (p. 68)

European Evangelical theologies were a by-product of the Age of Enlightenment, in which there was little or no belief in God. Thus, dualism, atheism, deism, secularism, scepticism, excessive materialism and secularism became the vogue. Hence, one of the reasons for the coming of Evangelism in Europe was to counter the ungodliness that had crept into the society. This made the Evangelicals, who now came as missionaries, to avoid speculative and philosophical theologies, made them emphasise on devotions and worshipall this as a measure of preserving the gospel from being corrupted by sideshows. This pushed some Evangelicals to view the dialogue between the gospel and culture as mere syncretism (mixture of religions) rather than as genuine inculturation and contextualising efforts. Any other culture, apart from the 'Christian culture', was not pure before God.
The CMS Evangelicals viewed such dialogues as threats to Christianity, a position that drove them to think of themselves as the only legitimate ambassadors of the gospel in Africa. They viewed themselves as custodians of a precious legacy of theology, 'which to all intents and purposes was complete and [hence, it] was their first duty to preserve and pass on intact' (Reynolds 1976:85). Like the servant who hid his talent and did not trade with it, in the Parable of the Talents (Mt 25:14-30), they too became transactional leaders who strived to maintain their status quo, rather than transformative leaders, who empower everyone and catapult people from the periphery to the high mountains of progress and growth. With transactionalists leading the parade, a theo-cultural clash was bound to emerge from time to time. Worst of all, the two diametrically opposed positions put up dogmatic loci that denied dialogue a chance. Such background information is critical in retracing the theo-cultural embargo that defined the first and second half of the 20th-century Kenya.

In their theological rigidity, the CMS Evangelicals could not tolerate the fact that the African worldview is a religious drama, as every 'aspect in the cosmos, every activity, space and time is expressed and experienced religiously' (Banana 1991:23). Such existential African realities were simply dismissed as satanic, and no dialogue with 'Satan' was entertained. To some, dialoguing with 'lost souls' and/or pagans would be tantamount to embracing an African goddess of the post-industrial revolution. As Chief Njega wa Gioko pushed them far from his 'more developed' areas to the less habitable hill of Mutira, they could not understand how a person who had 'never encountered God' could push 'God away from himself'. Such radical Evangelical positions, where dialoguing with the African worldview, would amount to betraying and/or compromising the Gospel in the Evangelical's view is the reason for the theo-cultural embargo that drove some to open their own African Instituted Churches. Such theo-social pitfalls led the Evangelical Lutheran Bishop of Bukoba, in the present-day Tanzania, Bengt Sundkler, to dismiss the rise of African indigenous churches (AICs) in the 1930s 'as the bridge over which Africans are brought back to heathendom' (Sundkler 1961:297). For a blocked-down flowing river, the mounting swelling was about to be catastrophic.

For Bishop Sundkler (1961:297), any dialogue between the culture and the gospel was satanic, and hence, he ignored the contextual nature of Christian theology. Like the CMS team, he was quick to dismiss indigenous religion as Fetishism and adherents as Fetish Worshippers (Idowu 1973:51), ancestral worship, the African God as a 'deus remotus' (a withdrawn God), paganism, dualistic, pantheistic, animistic, idolatry, heathenism, primitivism and polytheism (Parrinder 1962:21). Equally, there are African Christian Evangelicals who are rigid and dismissive of any dialogue between the gospel and culture. As mentioned by Allison M. Howell (1997), some African delegates noted, thus:

Rightly presented and understood, the gospel of Jesus Christ is capable of meeting the primal man (sic) at the point(s) of his 
greatest need, providing him with ultimate answers to his longings and effective ways of coping with the persistent problems in his life. Sometimes this will happen suddenly, but, more often than not, it is a process or processes of 'power encounter' between Christian and the primal world-views in which the former transforms the latter's view of God, man, and the 'powers' through Jesus Christ. (p. 15)

This dogmatic Evangelicalism is also found in Byang Henry Kato 'the first African General Secretary of the Association of Evangelicals in Africa and an outspoken critic of the dangers of syncretism and universalism in the African Church' (Manana 2021:1). In his infamous book, Theological Pitfalls in Africa (1975), he dismissed John Mbiti and Bolaji Idowu's efforts for dialogue between the gospel and culture (inculturation) as nothing but a theological pitfall. In their efforts for authenticating Christianity locally, he viewed it as major theological pitfalls that pose a threat to the very existence of Christianity in Africa, as the latter were promoting pernicious syncretistic universalism. Whilst still appreciating legitimate contextualisation of the Christian message in Africa, he still felt the need for an indigenous theology that was truly biblical and truly African.

For Kato, syncretistic universalism in Africa is evident when African indigenous religion is related to Christianity, which appears to contradict the vision of a truly biblical and truly Christian Africa (Manana 2021:1). To dismiss Mbiti, Idowu and the works of All Africa Conference of Churches as pitfalls was, in my view, the most extreme part of his dogmatic Evangelical theology which was clearly blind to the local initiatives. This resonates well with the position taken by the Evangelical European missionaries of the early 20th century. Kato, who died in the tourist city of Mombasa, Kenya, as he fell in a pit, irked the likes of Mbiti who claimed to have accepted his verbal face-to-face apology for insulting the local initiatives that seeks to Africanise Christianity in tropical Africa, in early 1970s (Gathogo 2011a:121). In reference to Byang Kato's book, Theological Pitfalls in Africa that was published in 1975, Mbiti (1979) noted thus:

The author launched a most bitter attack on myself (pp. 56ff. et passim), Professor E. B. Idowu (pp. 96ff. et passim), and ecumenism (pp.129ff.). At the end he proposed ten points on how to safeguard what he called 'biblical Christianity in Africa' (pp. 181ff.). Dr. Kato's passionate attack on fellow theologians and the ecumenical movement arose partly out of insufficient understanding on his part. I had the opportunity of discussing with him some of the issues, on December 9, 1975. At the end he apologized to me for having unjustifiably attacked me and promised to rewrite and change the relevant parts of his book. Ten days later, on December 19, 1975, Dr. Kato drowned on the shores of the Indian Ocean in Kenya. I learned a year later that before his tragic death Dr. Kato had actually written the parts he promised to revise, and the publisher of the book undertook to incorporate them into subsequent printings of the book. I give this personal note about Dr. Kato as an indication that he had no malicious intention in this book; he apologized to me and in the same spirit I am sure he would have made personal apologies to those others whom he had attacked. (pp. 119-120)
Furthermore, as noted in Bowers (1980):

Following the publication of [Theological] Pitfalls [in Africa] and just before his untimely death, $[$ Kato $]$ requested a meeting with Mbiti. During the course of a friendly discussion, and in response to objections from Mbiti, Kato apologized for the wording of certain passages in [Theological] Pitfalls [in Africa], and undertook to make adjustments accordingly in two paragraphs in the book in future printings. It was a worthy gesture, and worth reporting. It is equally worthwhile to note the inexcusable distortion of the subsequent printed accounts, which converted a modification of tone into a full-scale retraction of substance. Kato made no deathbed recantations! (pp. 30-31)

To this end, Balcomb (2016) describes the modern version of Evangelicalism in the 21st-century Africa, which resonates with the Evangelical European Missionaries of the early 20th century, thus:

These are conversionism, which emphasizes the need for personal conversion, activism which is to do with evangelizing others, Biblicism which is to do with the belief in biblical inerrancy, and crucicentrism which is to do with the centrality of the cross. The main problem with these criteria is that they carry an element of propositional value, as if to be an Evangelical you have to believe in certain things as doctrinal verities, of the order of a statement of faith. This kind of proposition-alism is typical of western Protestantism, and certainly of western Evangelicalism, but is far less appropriate for Africa where the existential circumstances and consequences of Evangelicalism are so different. (pp. 117-128)

\section{Legacies and pitfalls}

In post-colonial Kenya, particularly the 21st century, Evangelicalism has asserted its socio-economic and political influences in diverse forms. This is undoubtedly a carryover from the Evangelical European missionaries, and hence, their imprints are visible; albeit, sometimes negatively. Firstly, as early as 1921, an Evangelical European missionary, Archdeacon Walter Edwin Owen (1880-1945) of Kavirondo, in the presentday Western Kenya, had formed a political association after he led in converting the agitating Young Kavirondo Association (YKA), formed in December 1921, into the Kavirondo Taxpayers Welfare Association in June 1923 so as to teach Africans how to run their own affairs. For empowering the Africans, especially in modern agriculture and for supporting the pleas of African labourers in their farms, the European settler-farmers referred to him, derogatorily, as Archdemon (Gathogo 2016:273-278). The YKA formed by Canon Ezekiel Apindi, Jonathan Okwiri (Chair), Benjamin Owuor (Secretary), Simon Nyende (Treasurer) amongst others had covert support from Archdeacon Walter Owen (Githiga 2001:217).

It was easy, therefore, for Archdeacon Owen to lead the African founders in converting it into a welfare movement, where he empowered Africans by teaching them how to manage economic development (Githiga 2001:217). This led to the introduction of ploughs, watermills, new crops and bookkeeping as the secret of planned development. Over the years, he educated many Luo and Luhya civic and political leaders (Gathogo 2020b:281-384). Another European missionary, John 
William Arthur (1881-1952), of the Church of Scotland Mission (Presbyterian, an Evangelical outfit) went on to become the first person to represent the Africans in the Legislative Council (parliament) during the colonial era, for a period of 5 years during 1924-1929. This was after he was nominated by the colonial government to the so-called Legislative Council (Parliament) in 1924. The Rev. Dr. Arthur became a member of the Kenyan Executive Council that governed the colonial Kenya in 1928. He, however, resigned in 1929 after the central Kenya disturbances where Africans protested against socio-cultural suppressions in matters to do with polygamy, female circumcision and African dances. These concerns were being fought by both the missionaries and the colonial system. Hence, Dr. Arthur was not able to handle such issues that were mainly dealing with gospel and culture, resulting in conflict that exploded in 1929-1930 (Githiga 2001:28).

As Arthur was representing the African interests in the Legislative Council, a meeting was called, with his blessings, at Tumu Tumu, in the present-day Nyeri county. In this ecumenical conference of Evangelical missionary societies of March 1929, African practices, such as female circumcision, African dances, snuffing of tobacco, and polygamy, were condemned and tougher rules were made as a measure of enforcing this. These tougher rules included expelling children coming from polygamous homes from the missionary schools, blacklisting families that practised female circumcision and so on. In other words, the meeting was called in order to stamp out African religio-cultural practices, which the Evangelicals felt were inimical and/or incompatible with the gospel of Christ. In this meeting, it was resolved that 'female circumcision was evil and should be abandoned by all Christians [and that] all the Christians submitting to it should be suspended by all churches everywhere' (MacPherson 1970:108).

The eruption of gospel-culture conflict, which was basically Evangelical Christianity versus African indigenous religion, was clearly seen after the African nationalistic zeal was incorporated in these discourses. In particular, young men from the present-day Kiambu county started a religiopolitical dance to protest against the legalism of the Evangelicals. This dance song called Muthirigu (swingingdance song) ridiculed the missionaries, the colonial authorities, the uncircumcised girls and other concerns of the day. Muthirigu dance was followed by the the rise of the Arathi [dreamers and seers] adherents, the establishment of Kikuyu Independent Churches and schools, and the Aregi [anti-Evangelicals] exodus' (Wamue 1989:266). With Central Kenya getting divided into two irreconcilable groups, that is, pro-Evangelicals hence cultural abolitionists (Kirore minority) and the cultural nationalists (Karing' $a$ the majority), Muthirigu dance became the unifying glue. This dance was first sung at Thogoto, where the Evangelical Presbyterians under the Rev. Dr. Arthur had promoted Evangelical Christianity strongly. As a result of their dismissive and intolerant attitudes to the African cultural concerns, hence the failure to be quick to listen and 'slow to speak and [indeed] slow to anger' (James 1:19), the Evangelical European missionaries had provoked the anger of the African majority (Karing'a culturalists) who now united through the new protest dance.

As they mocked the Evangelical European missionary theologies and the colonial authorities in their Muthirigu dance, they touched on the divinity of Jesus, which they questioned. They also questioned the trinity, decried the European God, bemoaned the cultural biases of the Evangelicals, and the unholy alliances of the Evangelicals and the colonial authorities. In one of the Muthirigu songs, it says:

I thought Jesus was God or the Son of God. I have now found that he was an Indian or a picture or the prophet Mohammed....... Listen to the shocking news. The youth of the Kikuyu nation [of Kenya]: Any school run by an [Evangelical] European missionary is like a graveyard. (Kang'ethe 1981:28)

In the same spirit, they would praise their culture, religion, land and leaders. They would also mock collaborating Africans, thus:

$[M] y$ mother went through the rite, I will never change my culture and religion. I am told to marry one who has not gone through the rite but I say No. I am a Kikuyu and our religion was given by God. I have no enmity with any one save for the one who sells our land. I asked whether circumcision should continue. Kenyatta wa Muigai said it should continue... (Kang'ethe 1981:283)

Without a broad-based mass education on the above two schools of thought, a huge clash was bound to emerge, as the differences were largely fuelled by lack of knowledge (Hosea 4:6). In other words, Muthirigu was sung in defence of the people's religio-culture and as a call to the Evangelicals to be quick to listen to the other voices out there and be slow to dismissals of others' patterns of living. It was simply a call for inculturation, and hence, 'let's dialogue and/or reason together, as our common denominator is God' (cf. Is 1:18). It was also a call to stop acculturation and ethnocentrism in Christian missions, as Evangelicals felt that their EuroAmerican heritage was stronger than what they found, and hence, their urgency to replace the 'weaker culture'. Certainly, the two extremist positions needed to embrace plurality as God's economy for the world (Gathogo 2011b:24). As a mighty show of protest against the missionary ethnocentrism and acculturation, Muthirigu dance swept through central Kenya in an overnight. In turn, the struggle that had 'primarily involved the [African] Church elders had now been taken up by the youth. Soon, the situation would get out of hand and the government would step in' (Kang'ethe 1981:276-277), and banned it in early 1930. As it spread underground, it made the Karing'a (majority) more and more politically enlightened and angry. It is these agitated people who formed the Karing'a (African) Instituted Churches where afro-Biblical hermeneutics became the new norm (Gathogo \& Kinyua 2010:251-265). As noted by Kamuyu wa Kang'ethe (1981):

the dancers wore hats decorated with feathers; rattles on the ankles; wooden knives; and their clothes were decorated with beads. The leader played a Karing'aring'a, an instrument made 
of a piece of metal bent into a ring. This metal ring would be hit with a small metal rod and would produce the desired rhythmic sound. The partners danced facing each other and walked majestically as they followed their leader. The song was usually sung on Sundays. People would come from as far as Thika, Kiambu 'reserves', and adjacent suburbs of Nairobi to sing the Muthirigu at Kabete. Within a very short time the song-dance had spread throughout Gikuyu-land. (p. 279)

These decorations and/or paraphernalia, used in Muthirigu dance, demonstrate the determination of most Africans to keep their religion and culture and/or settle on anything else apart from dialogue of culture and gospel. Certainly, both groups displayed extremism in asserting their diverse positions. Whenever the government assisted the Evangelicals by arresting, detaining or jailing the African troublemakers, the more the movement became stronger. Furthermore, it made it appear that the colonial hegemony was synonymous to the Evangelical European missionary enterprise. Such misunderstandings blocked further rooms for dialogue and ironically magnified theo-cultural differences further.

\section{Evangelical influence in the political scene}

With the dismantling of colonialism in 1963, Rev Thomas Kuto Kalume of Malindi North (now Magarini) became the first ordained cleric to win a parliamentary seat via mass suffrage in December 1969. Afterwards, a Bishop from the Evangelical wing of Protestantism, Lawi Imathiu of the Methodist church, was nominated as a member of parliament from 1975 to 1979. Afterwards (Gathogo 2015):

\footnotetext{
... a number of clergy have plunged into politics, either as nominated or as elected MPs. In particular, Archbishop Stephen Oluoch Ondiek (1945-2011) of an African Instituted Church, Legio Maria, was elected as the MP for Ugenya in 1983. Other clerics who followed in Kalume's trajectory include: Prophetess Mary Wajiru of Kinangop, 1992-97; Bishop Allan Njeru of Mwea, 1992-97; Rev. Morris Dzoro of Kaloleni, 2002-2007; Rev. Moses Akaranga of Sabatia Constituency, 2002-2007 and later the Governor of Vihiga, 2013-2017; Bishop Margaret Wanjiru Kariuki of Starehe, 20072012; Rev. Mutava Musyimi of Gachoka, now Mbeere South, 20072017; and Bishop Robert Mutemi Mutua, 2013-2017, as a Wiper Party's nominated MP among others. (pp. 92-110)
}

At the continental levels, Frederick Jacob Titus Chiluba (19432011), the erstwhile trade unionist and a leading Evangelical Christian, won the Zambian multiparty presidential elections in 1991. He was the candidate of the leading opposition party, the Movement for MultiParty Democracy, and defeated the long-time President Kenneth Kaunda. Upon taking the instruments of power, from 1991 to 2002, Chiluba declared Zambia a Christian country, to the delight of Evangelicals in Zambia and the lager tropical Africa (Phiri 2006:401-428). Chiluba's lifetimes, however, place the Evangelical wing of Protestantism in a huge test and, indeed, in a daring pitfall. Firstly, he publicly separated, in 2000, with his second wife, Vera Tembo, with whom he had nine children. They finally divorced in 2001, after which Tembo pursued her own political career, and was elected in the Zambian Parliament and eventually became the Deputy Minister for Environment in 2006. Secondly, Chiluba married his third wife, Regina Mwanza, on 06 May 2002 (Phiri 2006:401-428).

In a conservative society, separation, divorce and remarriage did not build the reverberated Evangelical society that Chiluba had set to create in his earlier years of his presidency. Thirdly, the attempted coup of 1997 that made him declare a state of emergency and subsequently saw the jailing of suspects, the opposition leaders, detaining without charges, and even the arrest of the former president Kenneth Kaunda, made his 'Evangelical presidency' uglier, worrying and made it look like one, which was headed to the pitfall. Fourthly, his renunciation of standing for a third term in 2001, probably out of his Evangelical creed that he was the 'God's sent best for Zambia', left an egg on the face of Evangelicalism, as diverse interpretations were made on such a move. Some viewed it as greed for power, as power had entered his head, and was also seen as a betrayer to the Evangelical creeds of love and care and so on. He was, however, forced to abandon the quest for the unconstitutional third term and allowed Levy Mwanawasa to succeed him in an election that was disputed by some contestants. Fifthly, although he was successful in brokering peace amongst his neighbours, the Democratic Republic of Congo, he did not succeed in arresting the escalating crime and poverty in his home country, Zambia. Sixthly, his Evangelical presidency suffered more even after his retirement as he remained a subject of a long investigation and trials regarding alleged corrupt practices when he was in power (1991-2001). He was luckily acquitted 2 years before his death, at 68 years, in 2011 (Ranger \& Phiri 2008:38-46). Thus, although Chiluba created a more vibrant Evangelical civil society in Zambia, which was ready to play a socio-political role, it fell far short of the expectations for those who initially flirted with the idea of a Christian nation.

In the era of Kenya's President Daniel arap Moi (1978-2002), the influence of Evangelical theology was clear, especially in its initial stages. As a politician, who constantly preached and quoted biblical verses constantly, he was a member of the Evangelical African Inland Church, Moi began his presidency that fell short of declaring Kenya a Christian nation, as in the case of Zambia. Upon replacing Jomo Kenyatta, who almost declared himself an adherent of African indigenous religion, upon his death on 22 August 1978, Moi introduced his Evangelical-leaning working philosophy, which he called Nyayoism (from the Swahili word Nyayo, which means following the footsteps). Whilst he made it clear that he would follow his predecessor's economic policies, where the gross domestic product (GDP) was admirably growing at 7\% annually, he also made it clear that he was following the footsteps of his lord and saviour, Jesus Christ. He expounded on his Nyayo philosophy as comprising of three key words, namely, peace, love and unity, which are Christian virtues.

After the demise of the founding President Jomo Kenyatta on 22 August 1978 thus, the newly established President (Daniel Moi) appeared to have started well, encouraging the 
nation to preserve its environment by planting more trees, asking the citizens to do family planning, respect and care for the elderly, children, disabled and other marginal of the society. His introduction of Nyayo philosophy that stood on three pillars of peace, love and unity, noted above, made the likes of prophetic Clerics such as Archbishops David Gitari, Raphael Nzimbi and Zacchaeus Okoth; Bishops Zablon Nthamburi, Henry Okullu and Alexander Muge; vocal Clerics such as Timothy Njoya to find it compatible with the New Testament teachings, and hence, it was welcomed across the country. However, things turned for the worse when a fresh alertness towards government matters began to emerge after the constitutional amendment of 1982, which made Kenya a de jure one-party state. Soon afterwards, there was an attempted coup on 1 August 1982. With the attempt of overthrowing his government by some disgruntled members of the Kenya Air Force, the Kenya politics began to take a nosedive. Subsequent constitutional amendments that consolidated the power of the executive did not make matters any better, as the State became very intolerant to dissenting voices. As a result, some were reportedly abducted and killed; others were jailed or detained without trial.

From my viewpoint, and as a participant observer, it is in September 1984 when the erstwhile President, Daniel arap Moi (1978-2002), visited the graveyard of democracy and read out the following epitaph (Wamwere 2007):

I call on all ministers, assistant ministers and every other person to sing like parrots. During [the first post independent Kenyan President] Mzee [Jomo] Kenyatta's period [1963-1978], I persistently sang the Kenyatta tune until people said: 'This fellow has nothing to say, except to sing for Kenyatta'. I said: I did not have ideas of my own. Why was I to have my own ideas? I was in Kenyatta's shoes and, therefore, I had to sing whatever Kenyatta wanted. If I had sung another song, do you think Kenyatta would have left me alone? Therefore, you ought to sing the song I sing. If I put a full stop, you should put a full stop. This is how the country will move forward. The day you become a big person, you will have the liberty to sing your own song and everybody will sing it. (p. 17)

This is the intolerance that visited the post-colonial Kenya, and as one of the most detained Kenyans who remained in Kenyan jails for more than a decade, Koigi wa Wamwere who later became an Assistant Minister of Information and Communications in the Mwai Kibaki led government (20022012) says, the state was too intolerant to people who expressed their views freely:

The Kenyatta government was a one-party dictatorship [even though it did not legally outlaw multi-party political system]. To put out freedom of expression, Kenyatta detained his VicePresident, Jaramogi Oginga Odinga, Prof Ngugi wa Thiong'o, me and others. Mr Pio Gama Pinto and Mr JM. Kariuki were killed during his rule. The Moi government too was a one-party dictatorship. In 1982, it killed and buried freedom of expression when a change in the Constitution abolished multi-party democracy. But he was warned by Mr Waruru Kanja [a fiery Kenyan politician]: 'If you stop people from talking, they will fart'. In a few months there was an attempted coup [on 01 August
1982] under the pretext of which many were detained and thousands killed.... Under both Mr Kenyatta [1963-78] and Mr Moi [1978-2002], it was criminal to think, express oneself or even dream (sic). Kenya was like this when I went to study at Cornell University in the US [in 1965]. (Wamwere 2007:17)

Wamwere (2007) goes on to say:

There I heard people speak against their President. I attended student demonstrations against the war in Vietnam, apartheid in South Africa and black dictatorship in other African countries. In America I conceived the dream of freedom and returned home to fight for it. To fight for freedom, I became a journalist. For daring to write about people's problems, I was arrested almost every day. Police even came to our one-room house to sleep. Hoping to zip my mouth permanently, Mr Kenyatta detained me for four years. From detention, I vied for Parliament where I hoped to enjoy freedom of expression under parliamentary immunity. When I spoke for the poor, however, Mr Moi [the Evangelical leader] warned me: '[l]et sleeping dogs lie or you will lie yourself'. When I didn't heed Mr Moi's warning, he made me lie in prison for a whole nine years. After detention, I was driven into exile [Sweden and other Scandinavian countries] where I was a voice in the wilderness for a long time. From exile, I was charged with treason in our Kafka courts where I enjoyed even less freedom of expression than in Parliament. Finally, freedom day dawned and we are where we are today [referring to 2002 onwards or the Mwai Kibaki regime]. The freedom of expression we enjoy was fought for. It did not fall upon us like manna from heaven. (p. 17)

This 'backsliding' of leaders bred in an Evangelical setting, upon getting into power, reminds us of Lord John DalbergActon's (1834-1902) letter to the Anglican Archbishop Mandell Creighton in 1887. Acton (1887) who was concerned about the moral challenges in writing history and who also insisted that the same moral values should be expected from all leaders remarked thus:

I cannot accept your canon that we are to judge Pope and King unlike other men, with a favourable presumption that they did no wrong. If there is any presumption it is the other way against holders of power, increasing as the power increases. Historic responsibility has to make up for the want of legal responsibility. Power tends to corrupt and absolute power corrupts absolutely. Great men are almost always bad men, even when they exercise influence and not authority: still more when you super-add the tendency or the certainty of corruption by authority. There is no worse heresy than that the office sanctifies the holder of it. (p. 28)

Such scenarios where detentions and dictatorships were the order of the day infuriated the Church leaders; and in particular, the National Council of Churches of Kenya (NCCK), where Archbishop David Gitari was the Chairman (1978-1980 and 1982-1985). By 1985, the State had begun to remove popular Parliamentary and Party candidates who were considered to be critical to the governance of the country. To this end, the NCCK (formerly the National Christian Council of Kenya) organised a National Pastors' Conference in 1986 at Kenyatta University, in which Archbishop Gitari and other members of the Council took 
their radical stand against queue-voting system where rigging was rampant. In 1988, NCCK used its publication, Beyond, in order to document evidence of massive rigging and many other electoral malpractices during the years' of the general elections. Amidst intense criticism, this activism culminated in the banning of Beyond Magazine. As a result, two of NCCK's journalists (David Makali and Bedan Mbugua) were jailed in the notorious Manyani Prison! This did little to improve the relations between the Evangelical Protestant Church leaders and the government. Indeed, this general uneasiness and mistrust were to define their relationship for years to come until 29 December 2002 when the opposition took over under president Mwai Kibaki.

Thus, Moi's initial 'Evangelical presidency' (1978-1983), similar to the initial stages of Zambia's Chiluba, was a morale booster to all Evangelical Christians in Kenya and across the tropical Africa. Somewhere along the way, things got out of hand and the promising moments became missed opportunities. In both the Kenyan and the Zambian cases, we have noted the danger of blind adherence to Evangelical theology in political discourses. In both cases, thus, a philosophical re-evaluation of Evangelical contribution in the politics of the land is of paramount importance. It is unfortunate that both leaders 'succumbed to the temptations that accompany positions of power and tarnished the image of Evangelicals in politics as a result' (Balcomb 2016:126). To this end, Balcomb (2016) brings out the pitfalls in South African Evangelicalism, as in the Kenyan and Zambian case, when he says, thus:

In the South African context, for example, opposition to the apartheid regime by some Evangelicals translated into uncritical support for the forces of the democratic revolution which, on the other side of a changed status quo, translated into identification with the new ANC government until this also compromised them. On the other hand, those whose political quietism translated into support for the apartheid government in the name of obedience to scripture soon also found themselves thoroughly compromised with the apartheid regime. Evangelicals, in other words, have found it particularly difficult to navigate the tempestuous political waters of the sub-continent. (pp. 126-127)

\section{Conclusion}

This research article began by defining Evangelicalism as the brand of Christianity that places much emphasis on salvation through personal encounter with the risen Christ, on being 'born again', emphasis on the authority of the Bible as God's revelation to humanity, the crossing of frontiers so as to reach out to the 'lost world', conversion and proselytising practices, highlighting on inerrancy of the Bible and overt ways of expressing their Christian faiths. It also surveyed the CMS as an Evangelical strand, and then surveyed the legacies and pitfalls amongst African Evangelicals with special reference to the colonial Kenya and the post-colonial Kenya, which is the critical issue under consideration. Evangelicals in politics, the research article notes, have largely posted poor results save for
Archdeacon Owen of Kavirondo (Western Kenya) who formed a political party in 1921. The Moi era in Kenya (1978-2002) and the Chiluba regime (1991-2001) in Zambia had clear shortfalls that need to be addressed for posterity. Equally, extremism in the African's Muthirigu Dance, which was a theo-social protest of westernisation in all its theosocial dimensions, has also been captured. In exposing extremism on both sides of the divide, dialogue between gospel and culture (inculturation) remained a pipe dream, and hence, it is worthwhile to arrest this pitfall in the 21st century. This article has also established that the most elaborate Evangelical Movement in the 21st century is the Lausanne Movement whose vision is to take the whole gospel to the whole world. It has also demonstrated that both the colonial and post-colonial Evangelicalism have shortfalls, hence pitfalls, which need to be addressed so as to promote genuine growth in our respective areas. The challenge is to ensure that similar ideo-moral standards are applied in assessing both the African ecclesiastical (Evangelicals and non-Evangelicals) and political leaderships as a measure of mitigating the effects of power and its corrupting influences.

\section{Acknowledgements}

The author would like to thank the peer reviewers for their thorough assessment of the article that helped greatly in improving the original draft.

\section{Competing interests}

The author declares that he has no financial or personal relationships that may have inappropriately influenced him in writing this article.

\section{Author's contributions}

J.G. is the sole author of this article.

\section{Ethical considerations}

This article followed all ethical standards for research without any direct contact with human or animal subjects.

\section{Funding information}

The author acknowledges the Research Institute of Religion and Theology (UNISA) for its research output of 2020 that made it possible for him to complete this task.

\section{Data availability}

Data sharing is not applicable to this article as no new data were created or analysed in this study.

\section{Disclaimer}

The views and opinions expressed in this article are those of the author and do not necessarily reflect the official policy or position of any affiliated agency of the author. 


\section{References}

Al-Amin bin, A.S., 1995, The history of the Mazrui dynasty of Mombasa, transl. J. McL. Ritchie, Oxford University Press, London.

Balcomb, A.O., 2004, 'Left, right and the centre: Evangelicals and the struggle for liberation in South Africa', Journal of Theology for Southern Africa 118(1), 141-148.

Balcomb, A.O., 2016, 'Evangelicalism in Africa: What it is and what it does', Missionalia 44(2), 117-128.

Banana, C.S., 1991, Come and share: An introduction to Christian Theology, Mambo Press, Gweru.

Bowers, P., 1980, 'Mission and culture', Themelios: An International Journal for Pastors and Students of Theological and Religious Studies 5(3), 30-31.

Dalberg-Acton, J., 1887, 'Letter to Bishop Mandell Creighton, 5 April 1887', in J.N. Figgis \& R.V. Laurence (eds.), 1907. Historical essays and studies, pp. 27-29, Macmillan, London.

Gathogo, J., 2001, The truth about African hospitality: Is there hope for Africa?, Salt, Mombasa.

Gathogo, J., 2008, 'Missionaries and colonial authorities in Kenya', Swedish Missiological Themes 96(1), 43-70.

Gathogo, J., 2011a, Pangs of birth in African Christianity, Lambert, Saabrucken.

Gathogo, J., 2011b, Simplified sociology for beginners, Lambert, Saabrucken.

Gathogo, J., 2015, 'Ecclesiastical and political leaderships in one armpit: Reconstructing the memory of Thomas Kalume', Studia Historiae Ecclesiasticae 41(3), 92-110.

Gathogo, J., 2016, 'Retracing Diakonia in the East African Revival Movement', in R. Dowsett, I. Phiri, D. Birdsall, D.O. Terfassa, H. Yung \& K. Jørgensen (eds.), Evangelism and Diakonia in context, pp. 273-278, Regnum Books International, Evangelism
Oxford.

Gathogo, J., 2017, 'Evangelicals and public life in Kenya', in G. Heath \& D. Tarus (eds.), A Christian response to terrorism: The Kenyan experience, pp. 72-87, Pickwick Publications, Eugene, OR.

Gathogo, J., 2020a, 'Leven house factor in the birth of Digo Mission and Christian Empire in East Africa', Studia Historiae Ecclesiasticae 46(1), 1-15.

Gathogo, J., 2020b, 'Religion and civic participation in post-colonial Kenya: The case of Thomas Kalume', in E. Chitando, M.R. Gunda, L. Togarasei \& J. Kügler (eds.), Religion and development in Africa, pp. 281-304, University of Bamberg Press, Bamberg.
Gathogo, J. \& Kinyua, K., 2010, 'Afro-biblical hermeneutics in Africa today', Churchman $131(2), 251-265$.

Githiga, G., 2001, The church as the Bulwark against authoritarianism, Regnum, Oxford. Howell, A., 1997, The religious itinerary of Ghanaian people: The Kasena and the Christian gospel, Peter Lang, Frankfurt am Main.

Idowu, B., 1973, African traditional religion: A definition, SCM Press, London.

Kang'ethe, K., 1981, 'The role of the Agikuyu religion and culture in the development of the Karing'a religio-political movement, 1900-1950, with particular reference to the Agikuyu concept of God and the rite of initiation', Unpublished PhD thesis, to the Agikuyu concep
Nairobi University.

Lausanne Movement, 2021, Story of Lausanne, viewed 18 April 2021, from https:// lausanne.org/about-the-lausanne-movement.

MacPherson, R., 1970, The Presbyterian Church in Kenya, Presbyterian Press of East Africa, Nairobi.

Manana, F., 2021, 'Kato, Byang Henry (1936-1975) Evangelical Church of West Africa', Dictionary of African Christian Biography, viewed 18 April 2021, from https:// dacb.org/stories/nigeria/kato-byang/.

Mbiti, J., 1979, 'The biblical basis for present trends in African theology', in K. AppiahKubi \& S. Torres (eds.), African theology en route, pp. 119-124, Orbis Books, Maryknoll, New York, NY.

Okoth, A., 2006, A history of Africa: African societies and the establishment of colonial rule, 1800-1915, East African Educational Publishers, Nairobi.

Parrinder, G., 1962, African traditional religion, Sheldon Press, London.

Phiri, I.A., 2006, 'President Frederick J. T. Chiluba of Zambia: The Christian nation and democracy', Journal of Religion in Africa 33(4), 401-428.

Ranger, T.O. \& Phiri, I.A., 2008, 'President Frederick Chiluba and Zambia: Evangelicals and democracy in a Christian nation', in T.O. Ranger (ed.), Evangelical Christianity and democracy in Africa, pp. 38-46, St. Antony's College, Oxford.

Reynolds, J.S., 1976, The Evangelicals at Oxford 1735-1871, Marcham Manor Press, Oxford.

Sundkler, B., 1961, Bantu prophets in South Africa, Oxford University Press, London.

Wamue, G.N. \& Sandgren, D.P., 1989, 'Christianity and the Kikuyu: Religious divisions and social conflict', The Journal of Religion in Africa 22(3), 264-266.

Wamwere, K., 2007, 'Our long walk to freedom of speech', Sunday Nation, 22 July 2007, viewed 18 April 2021, from http://www.nationmedia.com/dailynation/ nmgcontententry. asp?category_id $=56$ \& newsid $=102850$. 